\title{
Diuron and Ametryn Runoff from a Plantain Field ${ }^{1}$
}

\author{
Lii-Chyuan Liu, Delia Fernández-Horta and Miguel Santiago-Córdova ${ }^{2}$
}

\begin{abstract}
The runoff losses of Diuron and Ametryn in water and sediment from a plantain field were determined during 1980 and 1981. The highest concentrations of Diuron and Ametryn residues detected in the water samples were $\mathbf{0 . 4 5}$ and $0.25 \mathrm{p} / \mathrm{m}$, respectively. The concentration of both herbicides in water decreased rapidly with time. Diuron residue was no longer detectable in water samples at the end of 16th week, while Ametryn residue took 9 weeks to fall below the detection limit. The highest concentrations of Diuron and Ametryn residue in the sediment were 5.80 and $1.13 \mathrm{p} / \mathrm{m}$. The concentrations of Diuron and Ametryn residue in the sediment at the end of this investigation were 0.20 and $0.14 \mathrm{p} / \mathrm{m}$, respectively. The total quantity of Diuron and Ametryn losses during the course of this experiment was estimated to be 7.7 and $5.6 \%$, respectively, of the total application.
\end{abstract}

\section{INTRODUCTION}

Ametryn [2-(ethylamino)-4-(isopropylamino)-6-(methylthio)-s-triazine] and Diuron [3-(3,4(dichlorophenyl)-1,1,-dimethylurea] are two principal preemergence herbicides widely used by local farmers for weed control in plantain (Musa acuminata $\times M$. balbisiana $\mathrm{AAB}$ ) fields. As most plantain plantations are located in the mountain region, runoff of the above-mentioned herbicides appears possible because of the high rainfall that often prevails. No information is available concerning the extent to which runoff of these herbicides may occur in a plantain field.

Pesticides runoff from agricultural fields has been a subject of prime concern. This concern is evidenced by the large volume of publications accumulated in recent years. Wauchope (6) reviewed the pesticide content of surface water draining from agricultural fields with many reports pertaining to herbicide runoff studies. In a subsequent publication, Wauchope and Leonard (7) suggested a semiempirical mathematical formula for predicting maximum pesticide concentration in agricultural runoff. The loss of Fluometuron in runoff water was determined under field conditions by Wiese et al. (8). The level of Fluometuron in runoff water was directly related to the slope of the land used for conducting the runoff experiments. Only $2 \%$ of the applied Fluometuron was lost in the situation predicting the highest concentration in runoff water. Using simulated amount of rain, Trichell et al. (5) found that more Dicamba and Picloram were lost from sod than bare soil. However, the loss of $2,4,5-T$ was about equal under both situations. Data for most of the

\footnotetext{
'Submitted to Editorial Board May 12, 1984.

${ }^{2}$ Phytophysiologist, Former Assistant Chemist and Research Assistant, Agricultural Experiment Station, University of Puerto Rico, Mayagüez Campus, Rio Piedras, P.R.
} 
above-mentioned herbicide runoff reports were obtained under temperate climatic and edaphic conditions. The only herbicide runoff conducted under environmental conditions similar to the one we report herein was that of Green et al. (2). They found that Atrazine and Ametryn dissipated rapirly in fields; neither was found normally in stream and estuarine sediments. Diuron, on the other hand, was sufficiently persistent in soils and sediments in nearly all sediment samples obtained at 6 month intervals at several sites for each estuary and its associated streams.

The objective of this research was to determine the magnitude of Diuron and Ametryn runoff from a selected plantain field. The concentrations and quantity of both herbicides detected in water and sediment samples could serve as a base for assessing the risk of applying these herbicides close to sensitive crops growing in the immediate vicinity.

\section{MATERIALS AND METHODS}

Two herbicide runoff experiments were carried out at Corozal Agricultural Experiment Substation, Corozal, Puerto Rico from 1980 to 1981. The soil used for this study was a Corozal clay (Ultisol) with a pH of 4.4 and organic matter content of $2.5 \%$; its cation exchange capacity was 17 meq per $100 \mathrm{~g}$ of soil. The area selected had slope of 10 to $12 \%$. Each experimental plot consisted of an area of $7.3 \times 27.4 \mathrm{~m}$ planted with 60 Maricongo plantain plants spaced at $1.8 \times 1.8 \mathrm{~m}$. A buffer zone of $7.3 \times$ $9.2 \mathrm{~m}$ was provided between the last row of plantain and collection pit. The collection pit $(0.91 \times 0.91 \times 1.2 \mathrm{~m})$ was located at the down slope end of buffer zone. Only the area planting to plantains was treated with herbicides. The water and sediment samples were collected weekly except in rare cases where excessive rain fell within a week. In the latter case two collections were made instead of one. The border of each experimental plot was slightly bedded so that all runoff water was channeled into the pit. A completely randomized block design with three replications was used in each experiment. The first experiment consisted of preemergence application of Diuron at $3.36 \mathrm{~kg}$ ai/ha starting on August 25, 1980. The second experiment included the preemergence application of Ametryn at $4.48 \mathrm{~kg}$ ai/ha beginning on March 19, 1981 at the same site. A sprinkler irrigation system was installed on the entire experiment area to simulate runoff. Each plot was equipped with sprinklers that were disconnected as soon as the water level in the pit reached the two-thirds of the filling capacity. During the rainy period, sprinkler irrigation was not needed as the rainfall was sufficient to cause natural runoff. Duplicate water samples were weekly collected after each runoff event. The remaining water in each pit was emptied into a draining ditch, and its total volume was registered. The quantity of sediment left over in each pit was also measured and sampled for herbicide determinations. 
The concentration of Diuron in water samples was determined by basifying $100 \mathrm{ml}$ of water and following the method described by Bleidner (1). One hundred grams of air-dry soil were treated with $100 \mathrm{ml}$ of $20 \%$ sodium hydroxide solution ( $20 \%$ ) for hydrolysis. The hydrolyzed quantity of Diuron was similarly determined as in the case of the water sample. The same volume of water and weight of soil were used for analyzing Ametryn. The water samples were extracted with methylene chloride without alumina cleanup and analyzed according to the uv method described by Mattson et al. (4). The extraction of Ametryn in soil was

TABLE 1.-Diuron concentration detected in water and soil sediment samples collected from a plantain field treated with $3.36 \mathrm{~kg}$ ai/ ha of the chemical

\begin{tabular}{cccc}
\hline \multirow{2}{*}{$\begin{array}{c}\text { Time in weeks after } \\
\text { herbicide application }\end{array}$} & $\begin{array}{c}\text { Rainfall or irrigation } \\
\text { received }\left(\mathrm{cm}^{3}\right)\end{array}$ & \multicolumn{2}{c}{$\begin{array}{c}\text { Diuroncentration } \\
(\mathrm{p} / \mathrm{m})\end{array}$} \\
\cline { 3 - 4 } 1 & 2.74 & 0.45 & 4.23 \\
2 & 2.46 & 0.15 & 5.80 \\
3 & 1.91 & 0.10 & 3.11 \\
4 & 2.54 & 0.12 & 2.10 \\
5 & 2.46 & 0.07 & 1.44 \\
6 & 1.16 & 0.05 & 1.67 \\
7 & 4.14 & 0.03 & 1.41 \\
8 & 2.29 & 0.01 & 1.14 \\
9 & 2.08 & 0.01 & 0.95 \\
10 & 2.34 & 0.02 & 1.20 \\
11 & 2.41 & 0.01 & 0.97 \\
12 & 1.45 & 0.02 & 0.96 \\
13 & 3.05 & 0.01 & 1.04 \\
14 & $3.05^{1}$ & 0.13 & 1.70 \\
15 & $4.98^{1}$ & 0.05 & 0.93 \\
16 & $9.47^{1}$ & 0.01 & 0.60 \\
17 & $1.40^{1}$ & ND & 0.27 \\
18 & $1.78+0.97^{1}$ & ND & 0.20 \\
& 1.96 & & \\
\hline
\end{tabular}

${ }^{\mathrm{I}}$ Rainfall.

done at reflux temperature using $10 \%$ water-acetonitrite as solvent and then analyzed following the uv method of Mattson et al. (4). The detection limit of both herbicides was $0.01 \mathrm{p} / \mathrm{m}$.

\section{RESULTS AND DISCUSSION}

The highest Diuron residue detected in water samples was $0.45 \mathrm{p} / \mathrm{m}$ during the first week after herbicide application (table 1). Diuron residues in water samples decreased rapidly with the passage of time. By the end of the 16th week, Diuron concentration was no longer detectable. The highest Diuron residue in the sediment was $5.80 \mathrm{p} / \mathrm{m}$ during the second 
week after herbicide application. Diuron residue in the sediment decreased at a slower pace than that detected in the water samples (table 1 ). By the end of the 18 th week, Diuron residue of $0.20 \mathrm{p} / \mathrm{m}$ were still present in the sediments. The quantity of Diuron residue loss in water and sediment is presented in table 2. The largest quantity of Diuron residue loss in water occurred during the first week after herbicide application, while that in sediment took place in the second week. The quantity of Diuron residue loss in water is calculated to be $2.7 \%$ of the

TABLE 2.-Accumulative quantity of Diuron collected from leachate and soil sediment in three replications of experimental plots treated with $3.38 \mathrm{~kg} \mathrm{ai} / \mathrm{ha}$ of the chemical

\begin{tabular}{|c|c|c|c|c|}
\hline \multirow[b]{2}{*}{$\begin{array}{l}\text { Time in weeks after } \\
\text { herbicide application }\end{array}$} & \multicolumn{2}{|c|}{ Water } & \multicolumn{2}{|c|}{ Sediment } \\
\hline & $\begin{array}{l}\text { Volume } \\
\text { collected }\end{array}$ & $\begin{array}{l}\text { Quantity } \\
\text { of Diuron } \\
\text { recovered }\end{array}$ & $\begin{array}{l}\text { Weight } \\
\text { collected }\end{array}$ & $\begin{array}{l}\text { Quantity } \\
\text { of Diuron } \\
\text { recovered }\end{array}$ \\
\hline & $L$ & $m g$ & $\mathrm{~kg}$ & $m g$ \\
\hline 1 & 1,317 & 664.6 & 55.3 & 256.3 \\
\hline 2 & 1,701 & 267.0 & 66.7 & 386.6 \\
\hline 3 & 970 & 97.3 & 42.0 & 128.1 \\
\hline 4 & 1,807 & 216.2 & 66.5 & 134.4 \\
\hline 5 & 1,492 & 101.1 & 45.3 & 83.9 \\
\hline 6 & 1,767 & 84.2 & 44.2 & 74.0 \\
\hline 7 & 1,578 & 39.2 & 49.7 & 60.9 \\
\hline 8 & 1,539 & 20.0 & 196.3 & 312.5 \\
\hline 9 & 1,843 & 24.5 & 128.9 & 185.7 \\
\hline 10 & 1,806 & 28.0 & 254.1 & 300.6 \\
\hline 11 & 1,445 & 17.1 & 61.1 & 75.0 \\
\hline 12 & 1,587 & 25.7 & 187.9 & 183.1 \\
\hline 13 & 856 & 8.6 & 77.4 & 82.1 \\
\hline 14 & 1,695 & 153.0 & 60.8 & 267.1 \\
\hline 15 & 380 & 21.1 & 924.4 & 835.3 \\
\hline 16 & 917 & 21.7 & 33.2 & 19.7 \\
\hline 17 & 1,467 & 0 & 42.8 & 11.6 \\
\hline 18 & 1,672 & 0 & 28.6 & 5.1 \\
\hline Total & 25,839 & $1,780.3$ & $2,365.2$ & $3,396.9$ \\
\hline
\end{tabular}

total quantity of Diuron applied and that in the sediment amounted to $5.0 \%$. A total of $7.7 \%$ of Diuron was recovered from water and sediment.

The highest Ametryn residue found in water samples was $0.25 \mathrm{p} / \mathrm{m}$ during the first week after herbicide application (table 3). Ametryn residue in water samples decreased slowly with time. By the end of 9 th week, Ametryn residue in water samples fell below the detection limit. The highest Ametryn concentration in the sediment was $1.12 \mathrm{p} / \mathrm{m}$ during the first week after herbicide application. By the end of 12 th week, Ametryn in the sediment was only $0.14 \mathrm{p} / \mathrm{m}$. The largest quantity of 
Ametryn residue loss in water occurred during the first week after herbicide application (table 4). However, the largest quantity of Ametryn loss in the sediment was detected during the second week after its application. The quantity of Ametryn loss in water is calculated to be $0.8 \%$ of the total quantity of Ametryn applied and that of the sediment

TABLE 3.-Ametryn concentration detected in water and soil sediment samples collected from a plantain field treated with $4.48 \mathrm{~kg}$ ai/ ha of the chemical

\begin{tabular}{cccc} 
Time in weeks after & Rainfall or irrigation \\
received $\left(\mathrm{cm}^{3}\right)$ & \multicolumn{2}{c}{$\begin{array}{c}\text { Ametryn concentration } \\
(\mathrm{p} / \mathrm{m})\end{array}$} \\
\cline { 3 - 4 } & $1.27^{1}$ & 0.25 & Water \\
\hline 1 & 20.34 & 0.06 & Sediment \\
\hline 3 & 8.53 & 0.04 & 1.07 \\
4 & $1.91^{1}$ & 0.02 & 0.64 \\
5 & 4.04 & 0.01 & 0.35 \\
6 & 3.89 & 0.01 & 0.23 \\
7 & 15.93 & 0.01 & 0.46 \\
8 & 9.75 & 0.03 & 0.45 \\
9 & 6.12 & ND & 0.30 \\
10 & 4.67 & ND & 0.26 \\
11 & 3.30 & ND & 0.19 \\
12 & 3.99 & ND & 0.14 \\
\hline
\end{tabular}

\footnotetext{
'Irrigation.
}

TABLE 4.-Accumulative quantity of Ametryn collected from leachate and soil sediment in three replications of experimental plots treated with $4.48 \mathrm{~kg}$ ai/ha of the chemical

\begin{tabular}{|c|c|c|c|c|}
\hline \multirow[b]{2}{*}{$\begin{array}{l}\text { Time in weeks after } \\
\text { herbicide application }\end{array}$} & \multicolumn{2}{|c|}{ Water } & \multicolumn{2}{|c|}{ Sediment } \\
\hline & $\begin{array}{l}\text { Volume } \\
\text { collected }\end{array}$ & $\begin{array}{l}\text { Quantity } \\
\text { of Ametryn } \\
\text { recovered }\end{array}$ & $\begin{array}{l}\text { Weight } \\
\text { collected }\end{array}$ & $\begin{array}{l}\text { Quantity } \\
\text { of Ametryn } \\
\text { recovered }\end{array}$ \\
\hline & $L$ & $m g$ & $\mathrm{~kg}$ & $m g$ \\
\hline 1 & 1,601 & 398.5 & 187.9 & 209.7 \\
\hline 2 & 1,862 & 107.6 & $2,970.6$ & $2,978.6$ \\
\hline 3 & 1,838 & 73.5 & 137.9 & 121.0 \\
\hline 4 & 1,476 & 29.4 & 77.4 & 45.9 \\
\hline 5 & 954 & 9.6 & 25.9 & 9.6 \\
\hline 6 & 1,056 & 15.4 & 93.9 & 26.5 \\
\hline 7 & 1,245 & 18.7 & 937.3 & 417.8 \\
\hline 8 & 884 & 35.2 & 939.3 & 416.2 \\
\hline 9 & 1,611 & - & 113.7 & 42.7 \\
\hline 10 & 1,758 & - & 43.1 & 11.9 \\
\hline 11 & 1,623 & - & 19.3 & 3.5 \\
\hline 12 & 1,253 & - & 11.1 & 1.8 \\
\hline Total & 17,161 & 687.9 & $5,557.4$ & $4,285.2$ \\
\hline
\end{tabular}


is estimated to be $4.8 \%$. A total of $5.6 \%$ of Ametryn residue was recovered from water and sediment.

On the basis of the highest Diuron residue concentration detected in the water samples $(0.45 \mathrm{p} / \mathrm{m})$, it appears that this concentration is low and would not cause any phytotoxic effect to sensitive crops. In vegetable crops, Liu and Irizarry (3) could not find any phytotoxic effect of Diuron to tomatoes, peppers and dry beans, grown on a calcareous soil of the southern coast treated with $0.80 \mathrm{p} / \mathrm{m}$ of the herbicides. The highest Ametryn concentration detected in the water sample was only $0.25 \mathrm{p} / \mathrm{m}$. This detected level of Ametryn is not likely to pose any deterimental effect on sensitive or non-target species. However, the Diuron residue concentration present in the sediment is considered high for first few weeks and the same holds true for Ametryn in the sediment. Considering the fact that this experiment was established on the land not quite as steep as the commercial plantation of plantain and the rains applied appeared to be on the lower end of climatic condition, precautions have to be taken with respect to sediment level of herbicides which might cause phytotoxic effects to plants on adjacent fields or in shallow ponds or backwaters below treated plantings.

\section{RESUMEN}

En 1980 y 1981 se estudiaron las pérdidas de Diuron y Ametryn por escorrentía en un platanal. Las concentraciones más altas de Diuron y Ametryn que se detectaron en las muestras de agua fueron 0.45 y 0.25 ppm, respectivamente. Las concentraciones de ambos herbicidas en el agua se redujeron rápidamente con el tiempo. El Diuron no fue detectable en las muestras de agua 16 semanas después de aplicado; lo mismo sucedió con Ametryn 9 semanas después. Las concentraciones más altas de Diuron y Ametryn el las muestras de sedimentos fueron 5.80 y 1.13 ppm, respectivemente. La cantidad de pérdida total de Diuron y Ametryn durante el transcurso de ese experimento se estimó en 7.7 y $5.6 \%$, respectivamente, del total aplicado.

\section{LITERATURE CITED}

1. Bleidner, W. E., Baker, H. M., Levitsky, M. and Lowen, W. K., 1954. Determination of 3-(p-chlorophenyl)-1,1-dimethlurea in soils and plant tissue, J. Agric. Food Chem. 2: 476-79.

2. Green. R. E., Goswami, K. P., Mukhtar, M. and Young, H. Y., 1977. Herbicides from cropped watersheds in stream and estuarine sediments in Hawaii. J. Environ. Qual. 6 (2): 145-54.

3. Liu, L. C. and Irizarry, H., 1982. Phytotoxicity to four vegetables of residue levels of Prometryn and Diuron in soil. J. Agric. Univ. P. R. 66 (3): 238-39. 
4. Mattson, A. M., Kahrs, R. A. and Murphy, R. T., 1970. Quantitative determination of triazine herbicides in soils by chemical analysis, Residue Rev. 32: 371-78.

5. Trichell, D. W., Morton, H. L. and Morales, M. G., 1968. Loss of herbicides in runoff water. Weed Sci. 16: 447-49.

6. Wauchope, R. D., 1978. The pesticide content of surface water draining from agricultural fields-a review, J. Environ. Qual. 7 (4): 459-72.

7. -- and Leonard, R. A., 1980. Maximum pesticide concentrations in agricultural runoff: a semiempirical prediction formula, J. Environ. Qual. 9 (4): 665-72.

8. Wiese, A. F., Savage, K. E., Chandler, J. J. and Liu, L. C., 1980. Loss of Fluometuron in runoff water. J. Environ. Qual. 9 (1): 1-5. 